\title{
Difficulties Students Face in Understanding Drama in English Literature at the Islamic University of Gaza (IUG)
}

\author{
Mahmoud Dawoud Ali Shakfa ${ }^{1}$ \\ ${ }^{1} \mathrm{PhD}$ candidate School of Education, Universiti Sains Malaysia, Malaysia \\ Correspondence: Mahmoud Dawoud Ali Shakfa, Lecturer at University College of Applied Sciences, Palestine. \\ Tel: 97-059-946-4768. E-mail: mshakfa@ucas.edu.ps
}

\author{
Received: March 23, 2012 Accepted: June 5, 2012 Online Published: July 27, 2012 \\ doi:10.5539/elt.v5n9p95 URL: http://dx.doi.org/10.5539/elt.v5n9p95
}

\begin{abstract}
The present paper explores the problems of English Language and Literature junior and senior majors, who are enrolled in a drama course at the Islamic University of Gaza (IUG). The course emphasizes the significance of drama. Morgan (1987: 7) defines drama as an "art of communication," which is essential in teaching literature. A survey was administered and the questionnaire consisted of of open and closed questions to have both quantitative and qualitative information of what each participant attributes to each facet of the study. The participants of the study consisted of 133 randomly selected students, which is $39 \%$ of the population of the current study. The population included both male and female students of "English Literature in the 20th Century" in the second semester (2006-2007). The data were analyzed using Pearson correlation, T-test independent sample, Spearman correlation, means and percentages, as well as Alpha Cronbach and Split-half. Findings showed that a majority of the students agreed that "reading drama is more common than watching it." Students face this major difficulty in learning drama. Over $70 \%$ of the students agreed that "students feel frustrated with the length of a play," "Extensive use of symbolism, similes, metaphor," and "writing style" were serious problems. Further research is strongly recommended to be conducted particularly in IUG, to fill in the gap among issues students face such as cultural, communicative, and linguistic facets in learning drama. The removal of these obstacles can benefit different aspects of learning and teaching drama and literature. These implications can be multi-dimensional in terms of linguistic, cultural, and communicative aims.
\end{abstract}

Keywords: English language and literature, drama, difficulty

\section{Introduction}

The purpose of this present paper is to investigate the aspects of drama in the learning and teaching of English language and literature. The focus of this current study is one of the most important subjects of investigation within the recent years.

Different researchers and authors, some of whom have devoted worthwhile surveys to the subject of literature and its significance, mention the importance of learning literature (Carter and Long 1991, Habib 1994, Zayda 1997, Ghosn 1998, Annaralla 1999, Keshta 2000, Dodson 2000, Carter and McRae 2001, Henning 2001, Shrimpton and Godinho 2002, Showlter 2003, McNaughton 2004, Crumpler 2005, Kornfeld and Leyden 2005, Bodden 2006, Costello 2006, Dupre 2006, Gina 2006, Gurley 2006, McNaughton 2006)

The Palestinian educational environment, specifically Islamic Gaza University, is not an exception. Even if students study literature, they always face problems or difficulties that make them unable to understand different courses, such as drama (Keshta 2000, Mourtaga 2004).

"English is a universal language: the language of communication among countries in the international world of trade, business, communications, air transportation and technology," according to Keshta (2000, p.1). In Palestine, English has become an essential demand for all levels and almost in all fields. The Palestinian government paid attention to the teaching of English as a second or foreign language and allocated 80 credit hours to English Language and Literature (Al-Breem 1999: 3). This move secures the interest and benefit for its people (Al-Breem 1999: 4-5). However, there are still problems in this context. For instance, Mourtaga (2004: 16) explains that the motivation towards English do not mean that all Palestinian students are good at English in spite of its importance.

Despite the great attention paid to English language development, there are some obstacles or problems (Keshta 2000: 44-45) in the way of the aspired development, such as the lack of proper arts for language learning and 
teaching. In addition, most English language and literature teachers in IUG are not selected based on the qualifications a professional is required to have. Thus, most students deal with problems in their learning literature and drama on their own (Shaqfa 2007).

Drama is a window that not only permits its audience to look into the cultural values of the people but also allows for reflecting a social life in which the reader can deduce and determine the culture and the way of living in any society (Keshta 2000: 53). This insight is in line with the definition of Morgan (1987: 7), in which he states that drama is an art of communication. In addition, Keshta cites that drama involves the whole living process from birth to death (2000: 53).

Based on the above reasons, the present paper reports the outcome of the research conducted on the difficulties of students taking the course of drama at IUG. For this purpose, the answers were derived from the multiple choice and open-ended questions in a questionnaire designed to respond to the aim of the present study. In drama, learners have the opportunity to express themselves in less controlled and more creative situations. This technique is an effective approach in foreign language teaching as well. The mentioned feature of drama helps the learners apply the language they have learned (Scheutz and Colangelo, 2004). Some scholars offer priceless information for colleagues who aspire on a smaller scale to achieve class objectives relating to drama (Dodson, 2000). Others talk specifically about drama on a larger scale and achieve out of class theatrical production goals (Bancheri, 1996; Moody, 2002; Savoia, 2002; Schultz and Heingk, 2002).

The learning of every language, including English, and the significance of each participating component and sub-component are closely dependent on the background of that language, such as the culture where that language is dominantly used. In this respect, literature paves the way to enlighten the path and the procedures employed in solving the difficulties students deal with in learning drama. Studies can help identify what students should know about the techniques involved in learning drama. These difficulties might range from linguistic to non-linguistic criteria since drama and literature, whether contemporary or old, are in line with the common cultural ground of the people who speak the target language.

\section{Research Objectives}

The objectives of the present study represent the research questions in every respect of the effects of drama learning among the English Language and Literature students of IUG. Finding solutions to the difficulties facing students can facilitate learning that specific subject matter. The current research paper provides a clear insight of the obstacles facing students learning drama in English literature at the IUG, Palestine. In addition, this present article targets some of the reasons behind low levels of English language among junior and senior students at the mentioned university. The objectives of the present research paper are as follows:

1. To discover the main difficulties students majoring in English Language and Literature face regarding the nature of drama

2. To find the importance of learning drama in a conducive environment

In an attempt to achieve the above mentioned objectives, the current research seeks to answer the following questions:

1. Is the low proficiency of students in the English language involved in their having difficulty with drama reading?

2. Which elements of drama make it difficult to be learned by students?

\section{Literature Review}

Many scholars confirm the fundamental role of English language and literature in the lives of people (Henning 2001, Shrimpton and Godinho 2002, Showlter 2003, McNaughton 2004). In addition, the lack of knowledge in English makes international communication impossible. Habib (1994:5) considers the value of literature in its attempt to explore, recreate, and seek for meaning in the human experience. At the university level, this importance is even more notable. Having access to new types of technology, recently published papers relate to different fields, updated textbooks and so on, makes English as a certain requirement for all university students. In this regard, the main method of learning a language acknowledges that literature is an inevitable part of communication. Different countries deem learning the English language as part of their priorities in their teaching and training aims. Some countries tailor the varieties of English and approaches to achieve their purposes.

Morgan (1987: 7) defines drama as "an art of communication." Drama is one of the most complicated forms of literature. Among the different literary works, drama needs a subtle arrangement of the language, which is the facet adding to its difficulty. 
In this sense, Showlter (2003: 84) states that basically "Plays are not meant to be read." In other words, if drama were meant to be read, there would be no chance of its correction to the addressee, while acting out the drama allows for such a modification. For instance, this is imaginable in a theater stage where modification and conveying of the true message of the drama can happen.

Drama and plays are written to be acted. Therefore, the role of the teacher is to bring out and transfer what is on the page to action. However, this creates a problem when it comes to the role of the students in non-English speaking countries with different languages and cultures.

Palestine, like other countries, considers the importance of English education. Teaching English language, including literature, is one of the main components of the Palestinian education curriculum. Consequently, the English department at the IUG realizes the importance of teaching English literature as a means of developing creative leaders. Therefore, 80 credit hours are devoted to English language and literature. Half of these courses are classified as Literature, in which instructors are normally free to organize and select the course content based on the course syllabus. These literature courses represent about one-third of the total requirements of the B.A degree in English Language (Al-Breem, 1999: 3). According to Al-Breem (1999: 4) most of the English Departments in Palestinian universities contain courses devoted to the study of language and literature.

Al-Breem (1999: 4-5) enumerates several characteristics of a literary course in Palestinian universities. The first component is that the material is selected based on the traditional approaches. In other words, instead of using the modern and up-to-date sources, the teachers mostly introduce the courses they had previously covered. Al-Breem continues that this selection of old material turns the students passive rather than active and participative. When students are asked to memorize what their instructors have read earlier, they become passive. In addition, students attempt to get a passing mark by memorizing sources they have covered rather than applying deep analysis (Shaqfa, 2007). According to Al-Breem (1999: 5), this practice affects the cognitive ability of the students.

Finally, Al-Breem (1999: 5) states that another prominent issue apparent in the Palestinian drama learning context is the lack of interest to follow the linguistic facets of the literary work among the instructors and the students. Furthermore, Al-Breem adds, "this can negatively affect the literary skills of the students and their capacity for literary appreciation."

For the purpose of the present study, removing those obstacles facing the learning of drama is a step towards achieving the flourishing aims in different realms of language, literature, and even culture.

\subsection{The Importance of Teaching Drama}

Several studies have been done to determine the importance of teaching literature in different perspectives and case studies. Ghosn (1998) presented four good reasons to use literature in the primary schools and integrate it into the English as a foreign language program, especially in cases where language proficiency was the ultimate goal of the learning-teaching process. However, it is limited to the classroom and school. The first reason states that authentic literature provides a motivating and meaningful context for language learning, and it presents natural language at its finest by promoting vocabulary development in context. The second reason cites that literature stimulates oral language and involves the child with the text while exposing him or her to some aspects of the target language culture. The third reason is that literature promotes academic literacy and critical thinking skills, and has the potential of fostering private interpersonal and intercultural attitudes. Finally, good literature deals with some aspects of the human condition and attempts to come to some understanding of life, either symbolically or metaphorically, and can contribute to the emotional development of a child (Ghosn, 1998).

Another study was conducted by Keshta (2000). The study examines the perception of foreign students regarding the understanding and teaching of English literature. In his study, Keshta investigated Gaza university student perceptions of drama and short stories in English with respect to (1) teaching approaches and strategies, (2) specific problems encountered, (3) benefits, and (4) reasons for studying literature. Keshta designed a questionnaire-based survey and randomly selected a sample of 147 foreign students majoring in English in Gaza universities to participate in the study. The study reports three major findings. First, major problems facing foreign students in learning drama in English literature were undertanding the theme, conflict, length of the play, and writing style. Second, major problems facing foreign students in learning short stories in English literature were vocabulary, writing style, character role, plot, and theme. Third, the appreciation of other cultures, evaluating and creating new ideas, and promoting language development were the beneficial components of understanding English literature.

Henning (2001) suggests relating literature and culture to undergraduate foreign language (FL) curriculum from the beginning through the advanced levels. The proposed curriculum is organized around socio-cultural and socio-historical values, attitudes, issues, and preferred literary texts in the broad sense. The role of literature in 
FL curricula is a means of presenting culture at the intermediate level, a separation between lower-division and upper-division FL courses, and are goals at intermediate-level courses. The study highlights an intermediate French sequence designed to integrate language, literature, and culture.

The course explores cultural values and attitudes, focusing on France and Quebec. To develop their cognitive abilities, linguistic skills, and cultural knowledge for success in higher division courses, students constructed their own goals. They also moved the foreign language curricula away from literary history and civilization courses that strive to make students uncultured without helping them understand the socio-cultural significance of what they are studying. The research focused on the importance of relating culture studies and literary history.

Shrimpton and Godinho (2002) discussed the differences in student engagement in small-group literature discussions and the strategies that teachers used to support student speech. Case studies were used, which draw on videotaped data from small-group literature discussions, interviews with teachers, and student focus groups to provide insights into teacher practice in small-group discussions. The research project was conducted in three schools located in the Melbourne suburbs. Approximately 120 children participated and 12 teachers were recruited from the three primary levels. The study found that what was emerging as more significant than gender-based differences in the ways that boys and girls engage in literature discussions was their socio-cultural positioning in the discussion process. They observed that the differences in student engagement in literature discussion were due to cultural and social understanding.

\section{Methodology}

The present research used the descriptive analytical method. A descriptive study, according to Brown and Rodgers (2002: 117), is "a research that describes group characteristics or behaviors in numerical terms." A questionnaire was designed to gather the data needed for the present study. In previous studies, asking an open-ended question to students and teachers allowed them to express their difficulties in learning drama. Leaving a space for the respondents to provide their points of view through the open-ended questions was the other way to extract their opinions about what they have figured out to be their problems in reading drama.

The questionnaire in the present study was developed to identify the main problems students face in learning drama. The questionnaire consisted of 25 items containing difficulties related to the nature of drama. The stated expressions fell in five scales: Strongly disagree (1), Disagree (2), No opinion (3), Agree (4), and Strongly agree (5).

Al Agha (1996: 121) believes that the internal consistency indicates the correlation of the degree of each item with the total average of the test. The internal validity coefficient was computed using the Pearson formula.

Table 1. Correlation coefficient at the items

\begin{tabular}{|c|c|c|c|}
\hline No. & Item & $\begin{array}{l}\text { Correlation } \\
\text { Coefficient }\end{array}$ & Significance \\
\hline 1 & Length of play & 0.505 & Sig. at 0.01 \\
\hline 2 & Use of old English & 0.427 & Sig. at 0.01 \\
\hline 3 & Writing style & 0.304 & Sig. at 0.05 \\
\hline 4 & Extensive use of symbolism, similes, metaphor. & 0.326 & Sig. at 0.05 \\
\hline 5 & Use of non English vocabulary & 0.337 & Sig. at 0.05 \\
\hline 6 & No chance for acting the play. & 0.358 & Sig. at 0.01 \\
\hline 7 & Lack of familiarity with culture and social context & 0.508 & Sig. at 0.01 \\
\hline 8 & Negative attitude towards drama. & 0.530 & Sig. at 0.01 \\
\hline 9 & Syllabus includes recent or modern plays. & 0.345 & Sig. at 0.05 \\
\hline 10 & Syllabus includes Muslim or Arab authors. & 0.294 & Sig. at 0.05 \\
\hline 11 & Lack of motivation towards drama. & 0.648 & Sig. at 0.01 \\
\hline 12 & Lack of fun. & 0.525 & Sig. at 0.01 \\
\hline 13 & Lack of participation and discussion. & 0.281 & Sig. at 0.05 \\
\hline 14 & No facilitators except teachers' notes. & 0.587 & Sig. at 0.01 \\
\hline 15 & The unawareness of the writer's background. & 0.407 & Sig. at 0.01 \\
\hline 16 & Students depend totally on the summery of teachers. & 0.359 & Sig. at 0.01 \\
\hline 17 & Watching drama is better than reading it. & 0.291 & Sig. at 0.05 \\
\hline 18 & Reading drama is not exciting. & 0.550 & Sig. at 0.01 \\
\hline 19 & Students do not study the whole play. & 0.539 & Sig. at 0.01 \\
\hline 20 & Students level is weak in English. & 0.313 & Sig. at 0.05 \\
\hline 21 & Students feel frustrated with the length of the play & 0.357 & Sig. at 0.05 \\
\hline 22 & $\begin{array}{l}\text { Students do not have the right to choose the text they } \\
\text { want to study. }\end{array}$ & 0.434 & Sig. at 0.01 \\
\hline 23 & Focusing on tragic drama & 0.427 & Sig. at 0.01 \\
\hline 24 & Shortage of literary references of drama. & 0.453 & Sig. at 0.01 \\
\hline 25 & Focusing on certain periods of literature. & 0.375 & Sig. at 0.01 \\
\hline
\end{tabular}


Table 1 shows the data analysis of the correlation coefficient of each item with the domain.

The provided tables represent the significance of the answers obtained through the questionnaire. These figures determine if there is any meaningful relation between the items provided earlier or not. For this purpose, the correlation coefficiencies are calculated using SPSS and whether they are significant (less than .05) or insignificant are shown in the table. The comparative analysis of the gained data indicates the degree of the importance each respondent, i.e. each student, ascribe to each criterion or item.

The results of Table 1 show that the value of the items suitable, highly consistent, and valid for conducting this study.

The population of the study consisted of both male and female students of the English department at IUG who registered for the course "English Literature in the 20th Century" in the second semester (2006-2007).This course acquaints the students with the main literary movements and the major writers of the 20th century. In taking advantage of some basic texts, the student is provided with a historical sense of the period together with some in-depth study of important works. The population of the study has 338 students, which consists of 67 males and 271 females.

The pilot sample of the present study comprised of 50 students out of the population of the study. The pilot study aims to ensure the reliability and the stability of the instrument of the study. The sample of the study consisted of 133 students constituting $39 \%$ of the population of the study. In selecting the participants, stratified random sample was used. All the students were in English language and literature field. The students were enrolled in the academic year (2006-2007) in the third and fourth levels.

Table 2. The distribution of the sample according to classification

\begin{tabular}{lllllll}
\hline $\begin{array}{l}\text { Marital } \\
\text { status }\end{array}$ & \multicolumn{2}{c}{ Junior } & \multicolumn{2}{c}{ Senior } & \multicolumn{2}{c}{ total } \\
\hline Gender & No. & \% & No. & \% & No. & \% \\
\hline Male & 16 & 12.03 & 29 & 21.80 & 45 & 33.83 \\
\hline Female & 10 & 7.52 & 78 & 58.65 & 88 & 66.17 \\
\hline Total & 26 & 19.55 & 107 & 80.45 & 133 & 100.00 \\
\hline
\end{tabular}

Table 2 shows the distribution of the sample according to classification and Table 3 shows it according to marital status.

Table 3. The distribution of the sample according to marital status

\begin{tabular}{lllllll}
\hline $\begin{array}{l}\text { Marital } \\
\text { status }\end{array}$ & \multicolumn{2}{c}{ Married } & \multicolumn{2}{c}{ Single } & \multicolumn{2}{c}{ Total } \\
\hline Gender & No. & \% & No. & \% & No. & \% \\
\hline Male & 1 & 0.75 & 44 & 33.08 & 45 & 33.83 \\
\hline Female & 25 & 18.80 & 63 & 47.37 & 88 & 66.17 \\
\hline Total & 26 & 19.55 & 107 & 80.45 & 133 & 100.00 \\
\hline
\end{tabular}

In order to analyze the data, the SPSS statistical package version 15 was used. As for analysis, the collected data were computed using Spearman correlation, Alpha Cronback, and Split-half techniques to confirm the validity and reliability. Means and percentages determined the main difficulties facing students in learning drama.

\subsection{Analysis and Result}

The main focus of the present study is on the investigation of the difficulties students face when learning drama, the word "difficulty" needs to be clarified. According to OD (2000), a difficulty is "a problem; a thing or situation that causes problems: e.g. the difficulties of English syntax." However, in this current study, difficulty refers to some obstacles facing the students in learning drama. Drama in the present study uses the definition of Khader (2007), which states that it "is a kind of literary composition meant to be enacted on the stage in which the story is told through dialogue, presenting characters placed in a situation of conflict and confrontation." 
Table 4. Frequencies and rank of each difficulty of the nature of drama

\begin{tabular}{|c|c|c|c|c|c|c|c|c|c|c|}
\hline$\stackrel{0}{z}$ & Difficulties & 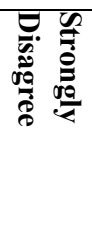 & 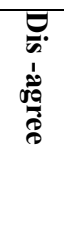 & $\begin{array}{l}\text { Z } \\
\text { ô } \\
\text { õ. } \\
\text { E. }\end{array}$ & $\frac{\overrightarrow{8}}{8}$ & 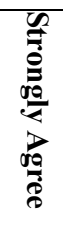 & $\stackrel{\mathscr{E}}{E}$ & $\frac{3}{3}$ & 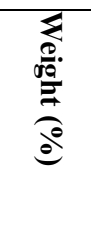 & $\begin{array}{l}\bar{\lambda} \\
\text { 龸 } \\
\bar{\lambda}\end{array}$ \\
\hline 1 & Length of play & 11 & 28 & 5 & 70 & 19 & 457 & 3.44 & 68.72 & 8 \\
\hline 2 & Use of old English & 16 & 35 & 4 & 46 & 32 & 442 & 3.32 & 66.47 & 10 \\
\hline 3 & Writing style & 9 & 16 & 14 & 73 & 21 & 480 & 3.61 & 72.18 & 5 \\
\hline 4 & $\begin{array}{l}\text { Extensive use of symbolism, similes, } \\
\text { metaphor. }\end{array}$ & 2 & 26 & 7 & 71 & 27 & 494 & 3.71 & 74.29 & 4 \\
\hline 5 & Use of non English vocabulary & 18 & 51 & 12 & 45 & 7 & 371 & 2.79 & 55.79 & 23 \\
\hline 6 & No chance for acting the play. & 26 & 25 & 9 & 47 & 26 & 421 & 3.17 & 63.31 & 14 \\
\hline 7 & $\begin{array}{l}\text { Lack of familiarity with culture and } \\
\text { social context }\end{array}$ & 18 & 36 & 3 & 53 & 23 & 426 & 3.20 & 64.06 & 12 \\
\hline 8 & Negative attitude towards drama. & 19 & 46 & 12 & 44 & 12 & 383 & 2.88 & 57.59 & 22 \\
\hline 9 & $\begin{array}{l}\text { Syllabus includes recent or modern } \\
\text { plays. }\end{array}$ & 21 & 32 & 19 & 46 & 15 & 401 & 3.02 & 60.30 & 19 \\
\hline 10 & $\begin{array}{l}\text { Syllabus includes Muslim or Arab } \\
\text { authors. }\end{array}$ & 39 & 29 & 19 & 30 & 16 & 354 & 2.66 & 53.23 & 25 \\
\hline 11 & Lack of motivation towards drama. & 21 & 42 & 10 & 46 & 14 & 389 & 2.93 & 58.50 & 20 \\
\hline 12 & Lack of fun. & 18 & 55 & 7 & 44 & 9 & 370 & 2.78 & 55.46 & 24 \\
\hline 13 & Lack of participation and discussion. & 13 & 49 & 2 & 43 & 25 & 414 & 3.14 & 62.73 & 16 \\
\hline 14 & No facilitators except teachers' notes. & 32 & 35 & 10 & 47 & 19 & 405 & 3.05 & 60.90 & 17 \\
\hline 15 & $\begin{array}{l}\text { The unawareness of the writer's } \\
\text { background. }\end{array}$ & 17 & 39 & 16 & 44 & 17 & 404 & 3.04 & 60.75 & 18 \\
\hline 16 & $\begin{array}{l}\text { Students depend totally on the summery } \\
\text { of teachers. }\end{array}$ & 17 & 29 & 5 & 39 & 43 & 461 & 3.47 & 69.32 & 7 \\
\hline 17 & $\begin{array}{l}\text { Reading drama is more common than } \\
\text { watching it. }\end{array}$ & 9 & 13 & 2 & 37 & 72 & 549 & 4.13 & 82.56 & 1 \\
\hline 18 & Reading drama is not exciting. & 15 & 58 & 4 & 37 & 19 & 386 & 2.90 & 58.05 & 21 \\
\hline 19 & Students do not study the whole play. & 14 & 26 & 10 & 45 & 38 & 466 & 3.50 & 70.08 & 6 \\
\hline 20 & Students level is weak in English. & 11 & 36 & 13 & 53 & 20 & 434 & 3.26 & 65.26 & 11 \\
\hline 21 & $\begin{array}{l}\text { Students feel frustrated with the length } \\
\text { of the play }\end{array}$ & 2 & 16 & 13 & 61 & 41 & 522 & 3.92 & 78.50 & 2 \\
\hline 22 & $\begin{array}{l}\text { Students do not have the right to choose } \\
\text { the text they want to study. }\end{array}$ & 10 & 18 & 8 & 41 & 56 & 514 & 3.87 & 77.29 & 3 \\
\hline 23 & Focusing on tragic drama. & 5 & 35 & 16 & 58 & 19 & 450 & 3.38 & 67.67 & 9 \\
\hline 24 & Shortage of literary references of drama. & 12 & 27 & 27 & 58 & 8 & 423 & 3.18 & 63.61 & 13 \\
\hline 25 & Focusing on certain periods of literature. & 10 & 46 & 11 & 47 & 19 & 418 & 3.41 & 62.86 & 15 \\
\hline
\end{tabular}

As shown in Table 4, the difficulties were arranged according to the percentage weight and rank related to the difficulties facing IUG students in learning drama. As noted in this table, over $82 \%$ of the students admitted that "Reading drama is more common than watching it." Moreover, over 70\% of the students agreed that "Students feel frustrated with the length of the play," "Students do not have the right to choose the text they want to study," "Extensive use of symbolism, similes, and metaphor," "Students do not study the whole play," and "Writing style were serious difficulties." Over $60 \%$ of the students identified "Students depend totally on the summary of teachers," "Length of play," "Focusing on tragic drama," "Use of old English," "Students level is weak in English," "Lack of familiarity with culture and social context," "Shortage of literary references of drama," "No chance for acting the play," "Focusing on certain periods of literature," "Lack of participation and discussion," "No facilitators, except teachers' notes," "The unawareness of the writer's background," and "Syllabus includes recent or modern plays" as specific difficulties they encountered. Finally, the least six difficulties were "Lack of motivation towards drama," "Reading drama is not exciting," "Negative attitude towards drama," "Use of non English vocabulary," "Lack of fun," and "Syllabus includes Muslim or Arab authors." 


\section{Conclusion}

After analyzing the data, the major and serious difficulties students face in learning drama in English literature according to its nature were noticed. The very significant fact was that reading the drama was considered more common than watching it. In addition other difficulties such as the length of the play, the themes, the right to choose the text for study, extensive use of symbolism, similes, metaphor, and writing style were the major difficulties facing the students in learning drama in English literature.

Based on the findings and as mentioned in the literature review about the role of the students, the role of the drama instructor is not an easy job. The primary criterion each literary instructor or drama teacher requires to know is in the aspect of creativity, which is dependent on the teaching style of the instructor. One of the major tasks of the instructor is the removal of the psychological barrier between students and literature and participation.

Another significant conclusion drawn from the points of view of the respondents and data analysis is that acting out various parts of drama is the most effective strategy in teaching drama. This is in line with the very first conclusion that reading drama is more common than watching it. In other words, the need to apply drama into real life can be considered a contributive aspect dealing with the difficulties in learning and teaching of drama. Finally, as an issue that can further studied, drama plays an essential role in bridging the gap between cultural differences. This conclusion is in line with the claim that drama and literature affect culture. In other words, the cultural aspects of the student studying drama should be considered. Cultural differences in the comprehension of foreign learners of drama and literary work must be given attention. However, this phenomenon should not be overgeneralized.

\section{Recommendation and Implications}

The most significant implication of the study benefits the English Language and Literature of the students in IUG who learn drama. By having an inclusive overview of the importance of drama and the role it plays as an "art of communication" (Morgan, 1987: 7), students and teachers can benefit from the learning and teaching drama for better communication. Secondly, curriculum developers and syllabus designers can benefit in recognizing the difficulties and try to include materials based on the findings proposed in the present study. Thirdly, the conclusion that acting out drama, rather than reading it, is an effective way in learning and teaching drama, should be taken into consideration in exposing the students to the theater. One way is to take the literature and drama students to the theatrical stage rather than remain inside the classrooms.

This present study recommends the establishment of a theater for the English department to have a venue, where it could stage some relevant plays to involve the students. Instructors can use more visual aids such as LCDs, videos, TV, and films in teaching drama. Using visual materials creates an atmosphere for students to become more engaged in the process of learning and appreciating drama.

Another recommendation is to focus on the importance of literature and drama in daily life, its role in progressing nations, and in creating new leaders. Instructors should allow the students to participate and use their previous knowledge, experience, and ideas in order to increase positive feelings towards drama. Moreover, it would be highly effective for English literature instructors if they include the teaching of culture when they teach literature. They should focus on cultural similarities and then on cultural differences to bridge the gap between Arab and English cultures.

Moreover, instructors should begin with modern drama to avoid archaic English vocabulary and teach students classical dramas at advanced level courses. It would be highly positive for English drama students to engage in discussion by using their skills in paraphrasing, comparing, and summarizing in order to develop fluency. Their participation will make them braver, more confident, and have more self-esteem. Encouraging students to participate in acting some episodes in the text itself gives them a chance for self-expression.

In addition, teachers must vary their techniques in teaching drama. Teachers should be cognizant of the cultural distance, which influences the understanding of drama and reinforces student confidence, particularly, those students whose opinions might be wrong.

More studies should be conducted to investigate the role of psychological and cultural factors on how students learn drama. Furthermore, it is suggested to teach and add many literary works by local researchers and authors, such as Arab authors, to the syllabus of IUG.

Drama, in particular, and literature, in general play important roles in conveying the cultural message of a people of an age (Morgan, 1987: 7), or at least their representatives of that specific time. The need to further investigate the relation between culture and literature interrelating with the role of linguistics in each realm is felt specially in 
Arab countries like Palestine (Keshta, 2000). Non-native learners of English literature face many cultural and linguistic differences, which sometimes turn to difficulties and barriers for the students and instructors. Overcoming these barriers needs to be tackled in later research.

\section{References}

Al Agha, E. (1996). The Educational Research: Elements, Methods and Tools. The Islamic University of Gaza.

Al-Breem, S. (1999). Studying the modern English Novel. Unpublished Doctor of philpsophy Thesis. University of Nottingham.

Annaralla, L. (1999). Using Creative Drama in the Multicultural Classroom.

Bayliss, P., \& Dodwell, C. (2002). Building Relationship Through Drama. Research in Drama Education, 7(1), 2002.

Bodden, L. M. (2006). Developing a creative classroom through drama work: One teacher's reflective journey. The University Of Arizona MAI 44/04, p. 1574 (Aug. 2006). Publication Number AAT 1432989.

Brown, J., \& Rodgers, T. (2002). Doing Second Language Research. Oxford: Oxford University Press.

Carter R., \& McRae, J. (2001). The Routledge History of Literature in England. London: Routledge.

Carter, R., \& Long, M. (1991). Teaching Literature. Hong Kong: Longman.

Carter, R., \& Nunan, D. (2005). The Cambridge Guide to Teaching English to Speakers of Other Languages. Cambridge: CUP.

Cortney, R. (1985). Rehearsing for Life: Teaching Drama Teachers. Paper presented at the meeting of the children's theater Association of America, Toronto, Ontario, Canada. ED263634. Retrieved from http://www.eric.ed.gov/

Costello, A. (2006). New Literacies in English: Integrating process drama and digital video in an urban, eighth grade classroom. State Universuty of New York at Buffalo. DAI-A 67/04, p. 1255 (Oct 2006). Publication Number AAT 3213945.

Crumpler, T. P. (2005). The role of educational drama in the composing processes of young writers. Research in Drama Education, 10, Issue 3, pp. 357-363, Nov, 2005. http://dx.doi.org/10.1080/13569780500276103

Dodson, S. (2000). Learning Languages through Drama.

Dupre, B. J. (2006). Creative drama, playwriting, tolerance, and social justice: An ethnographic study of students in a seventh grade language arts class. The University of New Mexico. DAI-A 67/06, p. 2083 (Dec 2006). Publication Number AAT3220936.

ERIC-NO: ED434378. Retrieved from http://www.eric.ed.gov/

ERIC-NO: ED468313. Retrieved from http://www.eric.ed.gov/

Ghosn, I. (1998). Four Good Reasons to Use Literature in the Primary School.

Gina, D. B. Teaching Literature and Language through Guided Discovery and Informal Classroom Drama. Research in Drama Education, 95, Issue 1, pp. 29-32, Sep, 2005.

Gurley, G. (2006). Drama and moral education: The plays of Maria Edgeworth (1768--1849). Arizona State University. DAI-A 67/06, p. 1981 (Dec 2006). Publication Number AAT 3220302.

Habib, A. (1994). An Eclectic Approach to Teaching Poetry. Unpublished Master Thesis. University of Nottingham: UK.

Habib, A. (2004). Teaching English Literature. Lectures presented to the students in The Islamic University of Gaza.

Hammond, J., \& Derewiamk, B. (2005). Genre cited in Carter. R., \& Nunan, D. (ed).

Henning, S. D. (2001). Relating Literature and Culture: Putting Theory into Practice at the Intermediate Level. ERIC-NO: ED46286. Retrieved from http://www.eric.ed.gov/

Hornby, A. S. (2000). OXFORD Advanced Learner's Dictionary. London: Oxford University Press.

Joyce, B., \& Weil, M. (1997). Models of Teaching. New Delhi: Prentice Hall of India.

Kempe, A. (2003). The Role of Drama in the teaching of Speaking and Listening as the Basis for Social Capital. Research in Drama Education, 8(1), 2003. 
Kennedy, X. J., \& Gioia, D. (2005). Literature: An Introduction to Fiction, Poetry and drama. London: Pearson Longman .

Keshta, A. (2003). Teaching English Language Literature to ESL Students in Developing Countries. Studies in Curriculum and Instruction, 85, 9-22.

Keshta, A. S. (2000). Alternative Approaches for Teaching English Literature to Undergraduate Students in Gaza Strip. Unpublished Doctor of Education Dissertation. University of Houston.

Khader, K. (2007). Introduction To Drama. Lectures presented to the students in The Islamic University-Gaza.

Klarer, M. (2003). An Introduction to Literary Studies. London: Routledge.

Kornfeld, J., \& Leyden, G. (2005). Acting out: Literature, Drama, and Connecting with History. UMI ProQuest: EJ738007. Retrieved from wwwlib.umi.com

Lennard, J., \& Luckhurst, M. (2002). The Drama Handbook. A guide to reading plays. Oxford: Oxford University Press.

McEvoy, S. (2006). Shakespeare The Basics. London: Routledge.

McNaughton, M. J. (2004). Educational Drama in the teaching of education for sustainability. Research in Drama Education, 10(2), 2004.

McNaughton, M. J. (2006). Learning from participants' responses in educational drama in the teaching of Education for Sustainable Development. Research in Drama Education, 11(1), 2006. http://dx.doi.org/10.1080/13569780500437572

Moody, H. L. B. (1981). Literary Appreciation. Singapore: Longman.

Morgan, M. (1987). Drama, Play, Theatre and Performance. Beirut: Longman Press.

Morison, R. (1993). Teaching Creative Drama. New York. Routledge.

Mourtaga, K. (2004). Investigating Problems among Palestinian Students. Published Ph.D Dissertation. London: Author House.

Richards, J. (2002). Curriculum Development in Language Teaching. Cambridge: CUP.

Richards, J., \& Rodgers, T. (2004). Approaches and methods in language Teaching. Cambridge: CUP.

Sajjad, H. (1991). A guide to Literary Criticism. New Delhi.

Saricoban, A. (2002). Reading Strategies of Successful Readers Through the Three Phases Approach. The Reading Matrix, 2(3), 2002. Retrieved from http://www.reading matrix.com/articles/sarcabon/article.pdf

Showlter, E. (2003). Teaching literature. Blackwell Publishing.

Shrimpton, B., \& Godinho, S. (2002). Exploring Differences in Students' Engagement in Literature Discussions. ERIC-NO: ED47395. Retrieved from http://www.eric.ed.gov/

Zayda, S. (1997). Children's Voices through Dramatic Play. ERIC-NO: 418344. Retrieved from http://www.eric.ed.gov/ 